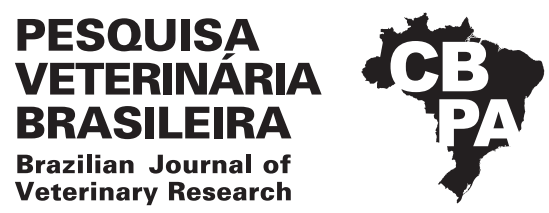

Pesq. Vet. Bras. 39(4):231-237, April 2019 DOI: 10.1590/1678-5150-PVB-6058

ISSN 0100-736X (Print)

ISSN 1678-5150 (Online)

\title{
Phytotoxins eliminated by milk: a review ${ }^{1}$
}

\author{
José Radmácyo G. Lopes²* (D) Franklin Riet-Correa ${ }^{3}$ and Rosane M.T. Medeiros ${ }^{2}$
}

\begin{abstract}
Lopes J.R.G., Riet-Correa F. \& Medeiros R.M.T. 2019. Phytotoxins eliminated by milk: a review. Pesquisa Veterinária Brasileira 39(4):231-237. Hospital Veterinário, Centro de Saúde e Tecnologia Rural, Universidade Federal de Campina Grande, Avenida Universitária s/n, Bairro Santa Cecília, Patos, PB 58780-110, Brazil. E-mail: macyo_mv@hotmail.com

Milk is a complex emulsion of lipids suspended in aqueous protein solution that can be a carrier of various contaminants, but generally it is not an important route of toxic excretion. The main problem is chronic repetitive exposure, as it occurs with ingestion of toxic plants and its potential danger to animals that consume the milk. Previously reported hazardous phytotoxins eliminated by milk include: indolizidine alkaloids, causing oligosaccharide storage disease; piperidine alkaloids, causing acute poisoning or malformations; pyrrolizidine alkaloids, which cause hepatic lesions; quinolizidine alkaloids, as a cause of skeletal defects; glucosinolates, which cause changes in the thyroid; tremetol (or tremetone), which causes a disease characterized by tremors in animals and milk sickness in humans; sodium monofluoracetate, which causes the death of kids after ingestion of colostrum from goats that have ingested Amorimia septentrionalis during gestation; ptaquiloside, which induces carcinogenesis in animals that ingest milk or derivatives produced by animals that have ingested Pteridium spp. Ipomoea asarifolia, which contains indole diterpenes causing tremors in suckling pups. Chrysocoma ciliata causes alopecia in suckling pups, but its toxic compound is still unknown. Knowledge about the risk of exposure to these substances via milk and its dissemination are important for veterinary and human health.
\end{abstract}

INDEX TERMS: Toxic plants, phytotoxins, elimination by milk, goats, milk, toxicoses.

RESUMO.- [Fitotoxinas eliminadas através do leite: uma revisão.] 0 leite é uma mistura complexa de lipídeos suspensos em solução aquosa de proteínas e pode ser veículo de diversos contaminantes, mas, geralmente, não é uma importante via de excreção de tóxicos. 0 principal problema é a exposição repetida, como ocorre com a ingestão de plantas tóxicas, e seu potencial perigo para os animais que consomem o leite. As fitotoxinas já descritas, que são eliminadas através do leite e podem causar danos à saúde incluem: alcaloides indolizidínicos, causam a doença do armazenamento de oligossacarídeos; alcaloides piperidínicos, que causam intoxicação aguda, pela sua capacidade de dessensibilizar os receptores nicotínicos da acetilcolina, ou malformações; alcaloides pirrolizidínicos, que provocam alterações hepáticas; alcaloides quinolizidínicos, que causam defeitos esqueléticos; glucosinolatos, que

\footnotetext{
${ }^{1}$ Received on September 14, 2018.

Accepted for publication on October 11, 2018.

${ }^{2}$ Hospital Veterinário, Centro de Saúde e Tecnologia Rural (CSTR), Universidade Federal de Campina Grande (UFCG), Avenida Universitária s/n, Bairro Santa Cecília, Patos, PB 58780-110, Brazil. *Corresponding author: macyo_mv@hotmail.com

${ }^{3}$ Instituto Nacional de Investigación Agropecuaria (INIA), Ruta 50 Km 11, Colonia, La Estanzuela, Uruguay.
}

provocam alterações na tireoide; tremetol (ou tremetone), que provoca, em animais, uma doença caracterizada por tremores, e em humanos, a doença conhecida como doença do leite; monofluoracetato de sódio, que causa a morte de filhotes após a ingestão do colostro de fêmeas que ingeriram Amorimia septentrionalis durante a gestação; ptaquilosídeo, que induz a carcinogênese em animais que ingerem leite ou derivados, produzidos por animais que ingeriram Pteridium spp. Ipomoea asarifolia contem indol diterpenos que causam tremores em filhotes lactentes. Chrysocoma ciliata causa alopecia em filhotes lactentes, porém seu princípio ativo tóxico ainda é desconhecido. 0 conhecimento e a divulgação sobre o risco da exposição a essas substâncias eliminadas através do leite são importantes tanto para a saúde animal quanto para a saúde humana.

TERMOS DE INDEXAÇÃO: Plantas tóxicas, fitotoxinas, eliminação através do leite, cabras, leite, caprinos, toxicoses.

\section{INTRODUCTION}

Milk can be defined as the whole product of the total or uninterrupted milking of a healthy, well-nourished, non-fatigued dairy female. On average, it is composed of $1 / 8$ of solid 
substances (fat, lactose, proteins, and minerals) and $7 / 8$ of water (Valsechi 2001).

Milk is a route of excretion of several contaminants, such as microorganisms, toxins, antibiotic residues, antiparasitics, and organochlorine pesticides (Heck et al. 2007). Milk contamination can occur before milking (indirect form), either by a pathogen infecting the animal, drugs used, or substances present in feed (Fink-Gremmels 2008), or during or after milking (direct form), through contamination by the milker's hands or machinery used in milking until the final industrialization process (Pereira 2011).

Because milk is a complex emulsion of lipids suspended in aqueous protein solution, it is considered a minor route of toxicant excretion. However, depending on the toxin concentration in the blood, the ability of a xenobiotic to diffuse across the cell membrane, its affinity for certain constituents in the milk, the efficiency of major detoxification and excretion routes (liver, urine, feces, etc.) and, specifically, the lipophilicity and basicity of the toxin and the type of plant toxin and its metabolites, toxicants can be irreversibly excreted in milk (Panter et al. 1988).

Milk may contain xenobiotics ranging from polar to lipophilic compounds; however, elimination of a toxin depends on its half-life in body water. The half-lives of most polar substances and the rapidly metabolized lipophilic compounds are usually short in milk, because these toxins are rapidly eliminated by the major routes of excretion. Thus, the percentage of the total amount of such compounds that is eliminated via milk is rather small. The main problem is chronic repetitive exposure, as it occurs from ingestion of poisonous plants and its potential danger to animals consuming the milk (Panter et al. 1988).

Some poisonous principles are readily excreted in milk, including those of high fat solubility that are concentrated in the lipid portion of the milk. These lipophilic xenobiotics have long biological half-lives and are frequently detected in milk at the highest concentrations and for the longest periods of time (Mathews 1980).

Elimination of plant toxins via milk is beneficial to lactating animals that ingest toxins; however, consumption of milk from intoxicated animals may induce intoxication in neonates or suckling animals. Poisoning that may occur in suckling offspring may be more severe than in lactating animals, because of toxin concentration in the milk, and young animals lack the ability to efficiently metabolize or detoxify xenobiotics (Panter \& James 1990).

Because of the importance of milk to public health and food safety, the need to determine the disposition of xenobiotics and, in particular, of natural phytotoxins in milk and other dairy products, is important. Therefore, the present study aimed to revise the main phytotoxins eliminated in milk and their potential danger to neonates and suckling animals.

\section{LITERATURE REVIEW}

\section{Phytotoxins eliminated by milk}

Indolizidine alkaloids. The main toxin in this group, called swainsonine, was first identified in Swainsona canescens (Colegate et al. 1979) and later in Oxytropis serecia and Astragalus lentiginosus (Molyneux \& James 1982). In Brazil, it is chiefly found in Ipomoea carnea subsp. fistulosa (Oliveira et al. 2009), Ipomoea riedelii, Ipomoea sericophyla (Barbosa et al. 2006), Ipomoea marcellia (Ipomoea verbascoidea)
(Mendonça et al. 2012), Turbina cordata (Dantas et al. 2007), and Sida carpinifolia (Driemeier et al. 2000).

Swainsonine inhibits activity of the lysosomal $\alpha$-mannosidase and Golgi $\alpha$-mannosidase II enzymes (Dantas et al. 2007), resulting in lysosomal accumulation of incompletely processed oligosaccharides and loss of cellular function followed by cell death (Riet-Correa et al. 2009), causing lysosomal storage diseases (Mendonça et al. 2012).

Regardless of palatability, animals that begin to ingest these plants develop the habit of ingesting them compulsively and, through a social facilitation mechanism, induce other animals of the same species to ingest them. Intoxicated animals show mainly nervous clinical signs, which include ataxia, hypermetria, lateral gait, spastic paresis, intention tremor, and widened base, and may also present somnolence, apathy, anorexia, progressive weight loss, and creepy hair (Dantas et al. 2007, Riet-Correa et al. 2009). The poisoning presents a chronic course, and animals can survive for several months after appearance of the clinical signs. If the animals fail to ingest these plants right after nervous clinical signs are observed or even 15-30 days afterwards, the signs are reversible (Riet-Correa et al. 2009). Histologically, intoxication is characterized by distension and vacuolization in the pericary of neurons, mainly of Purkinje cells of the cerebellum (Oliveira et al. 2009).

In a series of experiments conducted with suckling calves and lambs following a single oral exposure to swainsonine (Oxytropis serecia) (0.8 and 2.0mg of swainsonine for $\mathrm{kg}$ of body weight, respectively), this locoweed toxin was observed in the milk of both species and confirmed by quantification (Taylor \& Strickland 2002). James \& Hartley (1977) fed calves, lambs and kittens milk from cows that had ingested A. lentiginosus and later found that they showed microscopic lesions characteristic of poisoning caused by this plant, marked by neurovisceral cytoplasmic foamy vacuolization; increased amount of serum aspartate aminotransferase was also observed.

Piperidine alkaloids. The most common toxins in this group are found in Conium maculatum, causing skeletal defects in calves, piglets, and lambs born to dams that had ingested these toxins at certain stages of pregnancy (Panter et al. 1988). Perhaps the first notable example of poisoning by a member of this group of toxins was the death of Socrates in 399 BC. According to Plato's famous account in "Phaedo", the philosopher ingested C. maculatum, a plant with high concentrations of coniine and $\gamma$-coniceine (Reynolds 2005).

In humans, nicotine contained in domestic tobacco (Nicotiana tabacum) has been blamed for the occurrence of acute intoxications whose intensities range from mild to severe (Schep et al. 2009). Many other plants of the genera Nicotiana, Lobelia, Pinus, Duboisia, Sedum, Withania, Carica, Hydrangea, Dichroa, Cassia, Prosopis, Genista, Ammodendron, Lupinus, Liparia, and Collidium also contain piperidine alkaloids (Keeler \& Crowe 1985).

Consumption of plants with high contents of piperidine alkaloids can produce acute poisoning (Panter et al. 1999), characterized by frequent urination and defecation, tachycardia, muscle weakness and fasciculation, ataxia, collapse and, eventually, death due to respiratory failure (Panter et al. 1998).

Acute intoxications caused by piperidine alkaloids are assigned to their ability to desensitize the nicotinic 
acetylcholine receptors (Green et al. 2010) and inhibition of cation conduction $(\mathrm{Na}+, \mathrm{Ca} 2+$, and $\mathrm{K}+)$. Through their action at the neuromuscular junction, for instance, alkaloids cause transient fasciculation in the skeletal muscles, which are quickly followed by paralysis, progressing to respiratory failure (Arias 2000).

Many plants of these genera are consumed directly or indirectly by humans and animals, and some of them are used in human medicine. Piperidine alkaloids can be eliminated in milk, placing nursing infants at risk of toxicity and pregnant women at risk of teratogenicity. Few cases of transfer of piperidine alkaloids via milk have been reported, but maybe this is due to lack of research (Panter \& James 1990).

In 1980, there was an incident in which dairy cows were fed green chopped hay containing approximately $60 \%$ C. maculatum. It was reported that 160 lactating cows and 66 heifers were intoxicated. Subsequently, 10 cows and 14 heifers died, and an additional 14 cows and 12 heifers were slaughtered (Kubik et al. 1980). Piperidine alkaloids were detected using thin layer chromatography, and odor typical C. macularum was detected in the milk and urine of the cows. To avoid hazard to humans, the milk obtained for a period of several days was discarded (Panter \& James 1990).

Pyrrolizidine alkaloids. Pyrrolizidine alkaloids are naturally occurring phytochemicals in approximately 6,000 plant species of different genera and families (Smith \& Bababunmi 1980).

They are hepatotoxins that cause irreversible damage to the liver, and many of them may present carcinogenic action. Most plants containing pyrrolizidine alkaloids occur in three families, namely, Boraginaceae, Compositae, and Leguminosae. Senecio brasiliensis (Compositae) and Crotalaria spp. (Leguminosae) are the main plants associated with pyrrolizidine alkaloid intoxication in Brazil (Cheeke 1998).

In domestic animals, poisoning by plants containing pyrrolizidine alkaloids is mainly due to ingestion when there is shortage of pasture or through prolonged consumption of hay or grain contaminated with these plants, because these compounds present cumulative action (McLean 1970) and can cause a variety of symptoms, including hepatotoxicity, carcinogenicity, genotoxicity and pneumotoxicity (Boppré 2011).

In isolation, these alkaloids are nontoxic, but they become toxic when bio-transformed by the hepatic monooxygenase enzyme into a highly reactive form known as pyrrole (Prakash et al. 1999). The toxicity of pyrroles is associated with their high reactivity, acting as alkylating agents and easily binding to DNA molecules. In addition, pyrroles act by inhibiting mitosis in hepatocytes, leading to megalocytosis, necrosis and, consequently, reduction in the number of hepatocytes, which are replaced with fibrous connective tissue, giving rise to clinical signs and death owing to hepatic dysfunction (Santos et al. 2008). Part of the pyrroles escape into the general circulation, causing lesions in other tissues such as the kidneys and lungs (Radostits et al. 2002).

Natural poisoning can occur acutely or chronically, and is primarily characterized by apathy, anorexia, ascites, jaundice, photosensitization, incoordination, aggression, and head pressure against objects (Lucena et al. 2010).

Aiming to determine the transfer of pyrrolizidine alkaloids by milk, Medeiros et al. (1999) fed a goat with Crotalaria spectabilis seeds, which contain the pyrrolizidine alkaloid monocrotaline, and incorporated its milk into the diet of young rats for 60 days; at the end of the experiment, the pups showed lower weight gain and pulmonary and hepatic lesions compared with those in the control group. Goeger et al. (1982) fed lactating goats Senecio jacobaea, used their milk in the diet of rats for a prolonged period, and observed mild hepatic pathologies at the end of the experiment.

Quinolizidine alkaloids. Quinolizidine alkaloids are widely distributed among the legumes, which use them as a defense against predators because high concentrations of these toxins produce a bitter taste, limiting their consumption. The genus Lupinus is the richest of this type of alkaloid. In general, lupines have been used as fodder, green manure, and feed; in folk medicine, they are used as antitumor, antidiabetic, antioxidant and antifungal agents (Galasso et al. 2006).

Cytisine is a quinolizidine alkaloid found in an ornamental tree commonly known as the Golden Chain or Golden Rain (Laburnum anagyroides) and in plants of the genus Cytisus (Cheeke \& Shull 1985), and their seeds have caused intoxications in humans and horses characterized by excitation, incoordination, seizures, coma, and death by asphyxia (Kingsbury 1964).

Lupines contain the quinolizidine alkaloid anagyrine, which is known to cause skeletal defects and cleft palate in calves when their dams ingested Lupinos sp. during days 40 to 70 of gestation, shown to be a teratogenic alkaloid (Keeler 1978).

A case study of skeletal abnormalities in a child from California, USA, revealed that the primary source of milk consumed by the mother during pregnancy was from goats that had grazed lush pastures of lupine (Ortega \& Lazerson 1987). Among the herd, several goats spontaneously aborted and the fetuses showed skeletal defects similar to those of the calf disease reported by Keeler (1978). The mother recalled being clinically ill on many occasions after ingestion of the goats' milk. Further evidence implicating the milk from goats that ingested Lupinus was suggested after several puppies born to a bitch fed the same goats' milk during gestation showed similar malformations (Ortega \& Lazerson 1987).

Glucosinolates. Glucosinolates are glycosides of $\beta$-D-thioglucose that yield isothiocyanate, nitrite, thiocyanate or similar chemicals upon hydrolysis. They occur in the Cruciferae family, whose most of the glucosinolate-containing crucifers that are important in human or animal nutrition are in the genus Brassica, which includes cabbage, broccoli, kale, mustard, and turnips, among others. These compounds are responsible for the desirable taste in condiments such as mustard and horseradish sauces (Panter \& James 1990).

Goitrin, a hydrolyzed glucosinolate present in some plant species, inhibits thyroid function and causes thyroid hyperplasia and hypertrophy, inhibiting the incorporation of iodine into thyroxine precursors, interfering with the secretion of this thyroid hormone, and its anti-thyroid effect cannot be corrected by adding iodine to the diet. (Panter \& James 1990). Nitrites formed from glucosinolates are toxic, causing poor growth, liver and kidney lesions, bile duct hyperplasia, and liver necrosis (Paik et al. 1980).

Glucosinolates and their derivatives can be transferred to the milk of lactating animals, causing thyroid enlargement in young animals or in humans ingesting the milk; placental transfer of these compounds may also occur. Throckmorton et al. (1981) observed goiter and altered serum thyroid hormones in newborn 
lambs from ewes fed Limnanthes alba meal. In another study, White \& Cheeke (1983) goats fed L. alba 12 to 13 weeks prior to delivery. At birth, the lambs showed serum levels of thyroid hormones similar to those of animals in the control group; however, at weaning, these lambs presented lower serum levels of thyroid hormones and significantly lower body growth compared with the control animals. Also in this experiment, milk from the goats that ingested the plant was used as feed for growing rabbits, which showed heavier thyroid glands and higher mortality rate than those that received milk from the goats in the control group.

Tremetol (or tremetone). This toxin is found in white snakeroot, Eupatorium rugosum (Panter \& James 1990), a perennial herbaceous plant that usually grows in low and moist areas, close to streams and in open forests. During the dry season, when other forage lessens, animals are likely to move onto wooded areas and consume this plant. Quite often, this plant turns green and juicy in late autumn because it is protected from frost in its forest habitat (Cheeke 1998).

After ingesting E. rugosum for several days, cattle develop apathy and a condition known as "trembles", characterized by muscle tremors around the neck, shoulders and legs. The animals adopt a curved position; there is often the smell of acetone in their breath, wheezing, urinary incontinence, and constipation. Affected animals may recover, although there may be a long period of inappetence and muscle weakness. In severe poisoning, prostration evolving to death may occur (Cheeke 1998).

Tremetol can be transferred via the milk. Lactating animals seem to be less susceptible to intoxication than non-lactating ones because of their ability to eliminate such toxin in milk (Das et al. 2007).

The toxin can be transferred to humans via cow's milk, producing a serious debilitating disease referred to as "milk sickness", whose symptoms are weakness, nausea, prostration, ketosis, delirium, coma, and death. In the past, milk sickness sometimes reached epidemic proportions, and whole villages were abandoned because of it. It is said to be responsible for the death of Abraham Lincoln's mother, remaining unknown for many years until the early 1900's, when it was found to be due to the toxin present in E. rugosum (Cheeke 1998).

Clinical signs typically begin two days to three weeks after plant ingestion. Although modern techniques of milk treatment and pasture management have drastically reduced the risk of milk sickness, occasional cases can occur with milk produced in small farms without proper treatment or lack of weed control (Beier \& Norman 1990).

The same toxic constituents are also found in Haplopappus heterophyllus (Kingsbury 1964), which is a perennial, tall and erect plant commonly found in dry pastures in the southern USA states of Colorado, Texas, New Mexico, and Arizona, usually growing along irrigation canals, ditches, and river valleys. Significant losses of grazing animals have occurred in several parts of southwestern USA as a result of consumption of this plant. The clinical signs are as in intoxication by E. rugosum, with predominance of tremors. Intake of the green plant in the proportion of $1-1.5 \%$ of body weight for 1-3 weeks can cause toxicity in horses, cattle and sheep (Cheeke 1998).
Sodium monofluoracetate. Sodium monofluoracetate is a potent naturally occurring toxin in more than 50 plant species in Africa, Australia, and South America (Lee et al. 2014). In Brazil, 12 species are known, belonging to the families Rubiaceae, Bignoniaceae, and Malpighiaceae, causing sudden death syndrome associated with exercise (Carvalho et al. 2009), and sodium monofluoracetate was identified as the toxic agent that causes this syndrome. Owing to their severe toxicity, the Palicourea marcgravii, Palicourea aeneofusca and Amorimia septentrionalis species are among the most important toxic plants for ruminants in the Country (Tokarnia et al. 2012).

There are reports of intoxication outbreaks by these plants in sheep and goats in the state of Paraíba, Brazil (Vasconcelos et al. 2008). The following clinical signs were observed in experimentally intoxicated goats: dyspnea, tachycardia, and sternal decubitus evolving to lateral decubitus with pedaling movements, followed by death. Some less affected animals recover (Paraguassu 1983). In addition, ingestion of $A$. septentrionalis during pregnancy causes embryonic mortality and abortion in goats (Silva et al. 2017).

After goat and sheep producers mentioned that kids and lambs, born to dams that grazed in areas with plants of the genus Amorimia during gestation, died suddenly after colostrum ingestion, suggesting that sodium monofluoracetate can be excreted by milk, Vasconcelos et al. (2008) fed two pregnant goats with $A$. septentrionalis ( $2 \mathrm{~g}$ of fresh plant per kg of body weight) and reported that one kid from one of the goats died 5 min after sucking colostrum. Similarly, Lopes et al. (2018) fed eight pregnant goats ( $1 \mathrm{~g}$ of fresh plant per $\mathrm{kg}$ of body weight) and reported that four kids, born of two goats, received colostrum and presented with apathy, wheezing, lateral decubitus, bleating, and death after $15 \mathrm{~min}$; and two other kids from two goats that delivered during the night were found dead in the morning and, at necropsy, colostrum was found in the abomasum of both kids, indicating that they died after ingesting it.

Ptaquiloside. Described as the most toxic principle found in Pteridium arachnoideum (P. aquilinum), a plant popularly known as field fern or simply fern, ptaquiloside can act as a carcinogenic agent (Alvarenga 2015).

Fern is an invading plant with successful adaptation. Its only limitation regards distribution in extremely low temperatures (Rasmussen 2003). In Brazil, pastures invaded by fern have been reported in all states (Tokarnia et al. 2012).

Ptaquiloside is identified as a nor-sesquiterpene glycoside, amorphous, colorless compound, of formula $\mathrm{C}_{20} \mathrm{H}_{20} \mathrm{O}_{8}$, found in all structures of the plant, with the shoot apex as the aerial part of the plant with the largest content of that compound (Niwa et al. 1983). Ptaquiloside crosses the cell membranes and, in the nucleus, is able to associate with the proteins with exposed amino terminals, such as DNA (Alonso-Amelot \& Avendaño 2002), provoking permanent changes in genes that encode the activation of others, or that present regulatory function such as apoptosis regulation and tumor suppression (Santos et al. 1992).

The toxic and/or carcinogenic effect of fern varies according to the amount ingested, ingestion time, and the animal species involved (Tokarnia et al. 2012), and may cause hemorrhagic diathesis, bovine enzootic hematuria, and upper digestive tract carcinomas; occasionally, occurrence of thiamine deficiency, 
intestinal tumors, and progressive retinal degeneration are observed (Cruz \& Bracarense 2004).

Alonso-Amelot et al. (1998) fed six lactating cows fern (6kg/animal/day); 38 hours after the animals began to ingest the plant, $8.6 \pm 1.16 \%$ of the amount of ptaquiloside contained in the plant was identified in the milk. Alvarenga (2015) used $30 \%$ of the cheese produced from the milk of cows that had ingested $6 \mathrm{~g} / \mathrm{kg} /$ day of fern in the production of feed provided to rats for 176 days. At the end of the experiment, histopathology revealed that the animals that received feed containing cheese from the cows that ingested fern developed pre-neoplastic lesions (hyperplasia/dysplasia) in the stomach, intestines, and bladder, suggesting that the indirect consumption of ptaquiloside via the milk may induce carcinogenesis.

Studies have demonstrated that, even after pasteurization, part of the amount of ptaquiloside remains in the milk, and that there is positive correlation between the higher prevalence of gastric cancer in humans and permanence in areas invaded by fern (Alonso-Amelot \& Avendaño 2002).

Indole diterpene. Ipomoea asarifolia $\mathrm{R}$. et Schult. is a prostrate or climbing herbaceous plant belonging to the family Convolvulaceae (Tokarnia et al. 2012), native of South and Central America. In Brazil, it is very commonly found in the Amazon and Northeast regions, as well as along the coast, from the Northeast to the Southeast regions (Kissmann \& Groth 1992).

Ipomoea asarifolia provokes intoxication in cattle, sheep, goats, and buffaloes, especially during the dry season, when there is shortage of forage. The main clinical sign in the different species is muscular tremor that, beginning at the head, is characterized by continuous lateral movements (intention tremors). When animals are restless or scared, the tremors increase and become widespread in the body, with possible loss of balance and falls (Riet-Correa et al. 2003).

In sheep, poisoning was observed in suckling lambs that remained confined, without ingesting the plant, while their dams ingested the plant in the field, but without showing signs of intoxication, suggesting that the plant active principle was eliminated in the milk (Araújo et al. 2008). Initially, this hypothesis was confirmed in mice, when newly-born females began consuming feed containing 20\% I. asarifolia and, after two days, the suckling pups presented with tremors characterized mainly by lateral movements of the head, intensified when they were restless. The pups recovered 4 to 7 days after weaning (Lopes et al. 2014). Lucena et al. (2014) also demonstrated, but in sheep, that the toxic principle of I. asarifolia is excreted via milk of lactating females, when they observed that $50 \%$ of the lambs, although kept under confinement, showed tremors after ingesting the milk from ewes grazing in areas where the plant was present, or receiving 20\% dry leaves of $I$. asarifolia in their feed. The clinical signs disappeared 1-4 weeks after the end of plant consumption by the dams of the suckling lambs.

Recently, it has been demonstrated that Ipomoea asarifolia contains indole diterpenes (terpendol C; terpendol $\mathrm{K}$; 6,7-dehyro-11-hydroxy-12,13-epoxy-terpendol A; paxilline) that cause tremors in mice (Gardner et al. 2018).

Other phytotoxins. Several other phytotoxins or their metabolites are excreted via milk, namely, myosin (Leucaena leucocephala) (Ghosh et al. 2007), selenium compounds (Kenneth \& McConnell 1948), colchicine (Hale 1999), indole, and 3-methylindole (Eisele 1986), but they pose little risk because the amount eliminated is insufficient to cause intoxication.

\section{Phytotoxins not yet identified}

Chrysocoma ciliata L. (Asteraceae). Described as a dense, perennial shrub, approximately $500 \mathrm{~mm}$ in height, $C$. ciliata presents a rounded shape and numerous small leaves that are slightly sticky and bitter; it has been referred to as "bitter bush". C. ciliata is native of southern Africa, and is considered an invasive plant; dense concentrations of this plant indicate occurrence of overgrazing and pasture degradation. A herd will graze large amounts of bitter shrub only if more palatable species are not available (Vahrmeijer 1981).

This plant is associated with alopecia in lambs whose dams ingested the plant during gestation. The exact amount of plant that has to be ingested by sheep for their offspring present with alopecia is still unknown (Steyn 1931).

Steyn (1931) reported that a lamb, whose dam was fed $12.5 \mathrm{~kg}$ dry C. ciliata for 35 days developed alopecia and fatal diarrhea.

The unidentified toxin is transmitted via milk to the young, and this explains why the affected lambs or kids have normal hair at birth: because twins, which consume less milk, are less susceptible to alopecia than the individual offspring, and because the risk of alopecia can be reduced by partial emptying of the udders. Lambs or kids develop alopecia approximately three to 14 days after birth, rarely later. The first signs are pruritus and scratches or bites on the affected areas, often accompanied by swallowing of the hair. The hair becomes creepy and the fleece tufts can be easily pulled. Hair loss begins on the shoulders and sides of the body until eventually only remain at the ends (tail, lower limbs, ears) and at the top of the head. As a result of sun exposure, the hairless areas become reddish and tender, followed by cutaneous exudation and crust formation. In lambs, another common complication is bronchopneumonia, caused by exposure to cold winds. No primary gross lesions were found on the skin of the hairless areas. The non-pigmented skin is notably more easily affected than the pigmented parts. Morbidity in affected farms can range from $1 \%$ in dry years to $100 \%$ in extremely rainy years. Unless lambs are properly treated, more than $50 \%$ mortality can be expected (Steyn 1931).

The most appropriate treatment for affected animals is protection against sun rays and wind, with the use of emollient solution on the hairless areas to avoid hardening of the skin; and as a preventive measure, overgrazing in areas where the plant is present should be avoided (Steyn 1931).

\section{CONCLUSIONS}

Elimination of phytotoxins via milk, in addition to being a problem for production animals, is a public health concern, because it can directly or indirectly affect the health of humans.

Knowledge about the risk of exposure to these substances via milk and its dissemination are important for veterinary and human health.

Conflict of interest statement.- The authors have no competing interests 


\section{REFERENCES}

Alonso-Amelot M.E. \& Avendaño M. 2002. Human carcinogenesis and bracken fern: review of the evidence. Current Med. Chem. 9(6):675-686. <http:// dx.doi.org/10.2174/0929867023370743> <PMid:11945131>

Alonso-Amelot M.E., Castillo U., Smith B.L. \& Lauren D.R. 1998. Excretion, through milk, of ptaquiloside in bracken-fed cows, a quantitative assessment. Lait 78(4):413-423. <http://dx.doi.org/10.1051/lait:1998440>

Alvarenga T.M.P. 2015. Avaliação clínicopatológica de ratos alimentados com queijo de leite de vacas que consumiram Pteridium aquilinum. Master's Thesis, Universidade Federal de Lavras, Lavras, MG. 88p.

Araújo J.A.S., Riet-Correa F., Medeiros R.M.T., Soares M.P., Oliveira D.M. \& Carvalho F.K.L. 2008. Intoxicação experimental por Ipomoea asarifolia (Convolvulaceae) em caprinos e ovinos. Pesq. Vet. Bras. 28(10):488-494. <http://dx.doi.org/10.1590/S0100-736X2008001000008>

Arias H.R. 2000. Localization of agonist and competitive antagonist binding sites on nicotinic acetylcholine receptors. Neurochem. Int. 36(7):595-645. <http://dx.doi.org/10.1016/S0197-0186(99)00154-0><PMid:10771117>

Barbosa R.C., Riet-Correa F., Medeiros R.M., Lima E.F., Barros S.S., Gimeno E.J., Molyneux R.J. \& Gardner E.H. 2006. Intoxication by Ipomoea sericophylla and Ipomoea riedelii in goats in the state of Paraíba, Northeastern Brazil. Toxicon 47(4):371-379.<http://dx.doi.org/10.1016/j.toxicon.2005.11.010> $<$ PMid:16488457>

Beier R.C. \& Norman J.0. 1990. The toxic factor in white snakeroot: identity, analysis and prevention. Vet. Hum. Toxicol. 32(Suppl.):81-88. <PMid:2092409>

Boppré M. 2011. The ecological context of pyrrolizidine alkaloids in food, feed and forage: an overview. Food Addit. Contam. 28(3):260-281. <http:// dx.doi.org/10.1080/19440049.2011.555085><PMid:21360373>

Carvalho G.D., Nunes L.C., Bragança H.B.N. \& Porfírio L.C. 2009. Principais plantas tóxicas causadoras de morte súbitas em bovinos no estado do Espírito Santo, Brasil. Arch. Zootec. 58:87-98.

Cheeke P.R. \& Shull L.R. 1985. Natural Toxicants in Feeds and Poisonous Plants. AVI Publishing Company, Westport, Connecticut. 492p.

Cheeke P.R. 1998. Natural Toxicants in Feeds, Forages, and Poisonous Plants. $2^{\mathrm{a}}$ ed. Interestate Publishes Inc., Danville, Illinois. 479p.

Colegate S.M., Dorling P.R. \& Huxtable C.R. 1979. A spectroscopic investigation of swainsonine: an $\alpha$-mannosidase inhibitor isolated from Swainsona canescens. Aust. J. Chem. 32(10):2257-2264. <http://dx.doi.org/10.1071/ CH9792257>

Cruz G.D. \& Bracarense A.P.F.R.L. 2004. Toxicidade da samambaia (Pteridium aquilinum (L.) Kuhn) para a saúde animal e humana. Semina, Ciênc. Agrárias 25(3):249-258.

Dantas A.F.M., Riet-Correa F., Gardner D.R., Medeiros R.M., Barros S.S., Anjos B.L. \& Lucena R.B. 2007. Swainsonine-induced lysosomal storage disease in goats caused by the ingestion of Turbina cordata in Northeastern Brazil. Toxicon 49(1):111-116. <http://dx.doi.org/10.1016/j.toxicon.2006.08.012> $<$ PMid:17030054>

Das S., Manda G.P. \& Tyagi A.K. 2007. Milk toxicant of natural plant and feed mold origin: a review. Indian Dairyman 59:27-37.

Driemeier D., Colodel E.M., Gimeno E.J. \& Barros S.S. 2000. Lysosomal storage disease caused by Sida carpinifolia poisoning in goats. Vet. Pathol. 37(2):153159. <http://dx.doi.org/10.1354/vp.37-2-153> <PMid:10714644>

Eisele G.R. 1986. Distribution of indole in tissues of dairy cattle. swine, and laying pullets. Bull. Environ. Contam. Toxicol. 37(2):246-252. <http:// dx.doi.org/10.1007/BF01607757> <PMid:3742078>

Fink-Gremmels J. 2008. Mycotoxins in cattle feeds and carry-over to dairy milk: a review. Food Addit. Contam. 25(2):172-180. <http://dx.doi. org/10.1080/02652030701823142 > <PMid:18286407>

Galasso V., Przybył A.K., Christov V., Kovač B., Asaro F. \& Zangrando E. 2006. Theoretical and experimental studies on the molecular and electronic structures of cytisine and unsaturated keto-sparteines. Chem. Phys. 325(2-3):365-377.<http://dx.doi.org/10.1016/j.chemphys.2005.12.030>

Gardner D.R., Welch K.D., Lee S.T., Cook D. \& Riet-Correa F. 2018. Tremorgenic indole diterpenes from Ipomoea asarifolia and Ipomoea muelleri and the identification of 6,7-Dehydro-11-hydroxy-12,13-epoxyterpendole A. J. Nat. Prod.81(7):1682-1686.<http://dx.doi.org/10.1021/acs.jnatprod.8b00257> <PMid:30011204>

Ghosh M.K., Atreja P.P., Buragohain R. \& Bandyopadhyay S. 2007. Influence of short-term Leucaena leucocephala feeding on milk yield and its composition, thyroid hormones, enzyme activity, and secretion of mimosine and its metabolites in milk of cattle. J. Agricult. Sci. 145(04):407-414. <http:// dx.doi.org/10.1017/S0021859607007113>

Goeger D.E., Cheeke P.R., Schmitz J.A. \& Buhler D.R. 1982. Effect of feeding Milk from goats fed tansy ragwort (Senecio jacobaea) to rats and calves. Am. J. Vet. Res. 43(9):1631-1633. <PMid:7149409>

Green B.T., Lee S.T., Panter K.E., Welch K.D., Cook D., Pfister J.A. \& Kem W.R. 2010. Actions of piperidine alkaloid teratogens at fetal nicotinic acetylcholine receptors. Neurotoxicol. Teratology 32(3):383-390.<http:// dx.doi.org/10.1016/j.ntt.2010.01.011><PMid:20116429>

Hale T.W. 1999. Medications and Mothers' Milk. Pharmasoft Medical Publishing. 1096p.

Heck M.C., Sifuentes dos Santos J., Bogusz Junior S., Costabeber I. \& Emanuelli T. 2007. Estimation of children exposure to organochlorine compounds through milk in Rio Grande do Sul, Brazil. Food Chem. 102(1):288-294. <http://dx.doi.org/10.1016/j.foodchem.2006.05.019>

James L.F. \& Hartley W.J. 1977. Effects of milk from animals fed locoweed on kittens, calves and lambs. Am. J. Vet. Res. 38(8):1263-1265. <PMid:562113>

Keeler R.F. 1978. Alkaloid teratogens from Lupinus, Conium, Veratrum and related genera, p.397-408. In: Keeler R.F., Van Kampen K.R. \& James L.F. (Eds), Effects of Poisonous Plants on Livestock. Academic Press, New York. <http://dx.doi.org/10.1016/B978-0-12-403250-7.50045-5>.

Keeler R.F. \& Crowe M.W. 1985. Anabasine, a teratogen from the Nicotiana species, p.324-333. In: Seawright A.A., Hegarty M.P., James L.F. \& Keeler R.F. (Eds), Plant Toxicology. Queensland Poisonous Plants Committee, Queensland, Australia.

Kenneth B.Y. \& McConnell P. 1948. Passage of selenium through the mammary glands of the white rat and the distribution of selenium in the milk proteins after subcutane-ous injection of sodium selenate. J. Biol. Chem. 173(2):653657. <PMid:18910720>

Kingsbury J.M. 1964. Poisonous Plants of the United States and Canada. Prentice Hall Inc., Englewood Cliffs. 626p. <http://dx.doi.org/10.1097/00010694196411000-00022>.

Kissmann S. \& Groth D. 1992. Plantas Infestantes e Nocivas. BASF Brasileira S.A., São Paulo. 978p.

Kubik M., Refholec J. \& Zachoval Z. 1980. Outbreak of hemlock poisoning in cattle. Veterinarstvi 30(4):157-158.

Lee S.T., Cook D., Pfister J.A., Allen J.G., Colegate S.M., Riet-Correa F. \& Taylor C.M. 2014. Monofluoroacetate-containing plants that are potentially toxic to livestock. J. Agricult. Food Chem. 62(30):7345-7354. <http://dx.doi. org/10.1021/jf500563h $><$ PMid:24724702>

Lopes J.R.G., Riet-Correa F., Cook D., Pfister J.A. \& Medeiros R.M.T. 2014. Elimination of the tremorgenic toxin of Ipomoea asarifolia by milk. Pesq. Vet. Bras. 34(11):1085-1088. <http://dx.doi.org/10.1590/S0100736X2014001100009>

Lopes J.R.G., Araújo J.A., Pessoa D.A.N., Lee S., Riet-Correa F. \& Medeiros R.M.T. 2018. Mortalidade neonatal associada ao monofluoroacetato de sódio em cabritos alimentados com colostro de cabras ingerindo Amorimia septentrionalis. Pesq. Vet. Bras. (In publication)

Lucena K.F.C., Rodrigues J.M.N., Campos É.M., Dantas A.F.M., Pfister J.A., Medeiros R.M.T. \& Riet-Correa F. 2014. Poisoning by Ipomoea asarifolia in lambs by 
the ingestion of milk from ewes that ingest the plant. Toxicon 92:129-132. <http://dx.doi.org/10.1016/j.toxicon.2014.10.019> <PMid:25448387>

Lucena R.B., Rissi D.R., Maia L.A., Flores M.M., Dantas A.F.M., Nobre V.M.T., RietCorrea F. \& Barros C.S.L. 2010. Intoxicação por alcaloides pirrolizidínicos em ruminantes e equinos no Brasil. Pesq. Vet. Bras. 30(5):447-452. <http:// dx.doi.org/10.1590/S0100-736X2010000500013>

Mathews H.B. 1980. Elimination of toxicants and their metabolites, p.175176. In: Hodgson E. \& Gulhrie F.E. (Eds), Introduction to Biochemical Toxicology. Elsevier North Holland Inc., New York.

McLean E.K. 1970. The toxic actions of pyrrolizidine (Senecio) alkaloides. Pharmacol. Rev. 22(4):429-483. <PMid:4921839>

Medeiros R.M.T., Gorniak S.L. \& Guerra J.L. 1999. Effects of Milk from goat fed Crotalaria spectabilis seeds on growing rats. Braz. J. Vet. Res. Anim. Sci. 36(2):97-100. <http://dx.doi.org/10.1590/S1413-95961999000200008>

Mendonça F.S., Albuquerque R.F., Evêncio-Neto J., Freitas S.H., Dória R.G.S., Boabaid F.M., Driemeier D., Gardner D.R., Riet-Correa F. \& Colodel E.M. 2012. Alfa-mannosidosis in goats caused by the swainsonina-containing plant Ipomoea verbascoidea. J. Vet. Diagn. Invest. 24(1):90-95. <http:// dx.doi.org/10.1177/1040638711425948><PMid:22362938>

Molyneux R.J. \& James L.F. 1982. Loco intoxication: Indolizidine alkaloids of spotted locoweed (Astragalus lentiginosus). Science 216(4542):190-191. <http://dx.doi.org/10.1126/science.6801763> <PMid:6801763>

Niwa H., Ojika M., Wakamatsu K., Yamada K., Hirono I. \& Matsushita K. 1983. Ptaquiloside, a novel norsesquiterpene glucoside from bracken, Pteridium aquilinum var. latiusculum. Tetrahedron Letters 24(38):4117-4120. <http:// dx.doi.org/10.1016/S0040-4039(00)88276-3>

Oliveira C.A., Barbosa J.D., Duarte M.D., Cerqueira V.D., Riet-Correa F., Tortelli F.P. \& Riet-Correa G. 2009. Intoxicação por Ipomoea carnea subsp. fistulosa (Convolvulaceae) em caprinos na Ilha de Marajó, Pará. Pesq. Vet. Bras. 29(7):583-588. <http://dx.doi.org/10.1590/S0100-736X2009000700014>

Ortega J.A. \& Lazerson J. 1987. Anagyrine-induced red cell aplasia, vascular anomaly, and skeletal dysplasia. J. Pediatr. 111(1):87-89. <http://dx.doi. org/10.1016/S0022-3476(87)80349-9><PMid:3110390>

Paik I.K., Robblee A.R. \& Clandinin D.R. 1980. Products of the hydrolysis of rapeseed glucosinolates. Can. J. Anim. Sci. 60(2):481-493. <http://dx.doi. org/10.4141/cjas80-057>

Panter K.E. \& James L.F. 1990. Natural plant toxicants in milk: a review. J. Anim. Sci. 68(3):892-904. <http://dx.doi.org/10.2527/1990.683892x> $<$ PMid:2180885>

Panter K.E., Bunch T.D. \& Keeler R.F. 1988. Maternal and fetal toxicity of poison hemlock (Conium macularum) in sheep. Am. J. Vet. Res. 49(2):281283. <PMid:3348538>

Panter K.E., Gardner D.R. \& Molyneux R.J. 1998. Teratogenic and fetotoxic effects of two piperidine alkaloid-containing lupines (L. formosus and L. arbustus) in cows. J. Nat. Toxins 7(2):131-140. <PMid:9678187>

Panter K.E., James L.F. \& Gardner D.R. 1999. Lupines, poison-hemlock and Nicotiana spp. toxicity and teratogenicity in livestock. J. Nat. Toxins 8(1):117-134. <PMid:10091132>

Paraguassu A.A. 1983. Intoxicação experimental por Mascagnia rigida Grisebach (Malpighiaceae) em caprinos no Nordeste do Brasil. Master's Thesis, Universidade Federal Rural do Rio de Janeiro, Seropédica, RJ. 65p.

Pereira D.A. 2011. Fatores impactantes na qualidade do leite de tanques comunitários na microrregião de Juiz de Fora-MG. Master's Thesis, Universidade Federal de Juiz de Fora, Juiz de Fora, MG. 112p.

Prakash A.S., Pereira T.N., Reilly P.E. \& Seawright A.A. 1999. Pyrrolizidine alkaloids in human diet. Mutation Res. 443(1/2):53-67. <http://dx.doi. org/10.1016/S1383-5742(99)00010-1> <PMid:10415431>
Radostits O.M., Gay C.C., Blood D.C., Hinchliff K.W., Arundel J.H., Figueiredo C., Jacobs D.E., Leslie B.O., Mckenzie R.A. \& Bildfell R.J. 2002. Clínica veterinária: um tratado de doenças de bovinos, ovinos, suínos, caprinos e equinos. Guanabara, Rio de Janeiro. 1737p.

Rasmussen L.H. 2003. Ptaquiloside an environmental hazard? Occurrence and fate of a Bracken (Pteridium sp.) toxin in terrestrial environments. Doctoral Dissertation, The Royal Veterinary and Agricultural University, Denmark. 124p.

Reynolds T. 2005. Hemlock alkaloids from Socrates to poison aloes. Phytochemistry 66(12):1399-1406. <http://dx.doi.org/10.1016/j. phytochem.2005.04.039><PMid:15955542>

Riet-correa F., Medeiros R.M.T., Pfister J.A., Schild A.L. \& Danta S.A.F.M. 2009. Poisonings by plants, mycotoxins and related substances in Brasilian livestock. Pallotti, Santa Maria. 246p.

Riet-Correa F., Tabosa I.M., Azevedo E.O., Medeiros R.M.T., Simões S.V.D., Dantas A.F.M., Alves C.J., Nobre V.M.T., Athayde A.C.R., Gomes A.A. \& Lima E.F. 2003. Doenças dos ruminantes e equinos no semi-árido da Paraíba. Semi-árido em Foco, Patos, 1(1):2-86.

Santos J.C.A., Riet-Correa F., Simões S.V.D. \& Barros C.S.L. 2008. Patogênese, sinais clínicos e patologia das doenças causadas por plantas hepatotóxicas em ruminantes e eqüinos no Brasil. Pesq. Vet. Bras. 28(1):1-14. <http:// dx.doi.org/10.1590/S0100-736X2008000100001>

Santos R.C., Brasileiro Filho G. \& Silva M.E. 1992. Tumorigenicity of boiling water extract of bracken fern (Pteridium aquilinum (L.) Kuhn). Ciênc. Tecnol. Aliment. 12:72-76.

Schep L.J., Slaughter R.J. \& Beasley D.M. 2009. Nicotinic plant poisoning. Clin Toxicol. 47(8):771-781. <http://dx.doi.org/10.1080/15563650903252186> <PMid:19778187>

Silva L.C.A., Pessoa D.A.N., Lopes J.R.G., Santos J.R.S., Olinda R.G. \& Riet-Correa F. 2017. Embryonic death and abortions in goats caused by the ingestion of Amorimia septentrionalis. Pesq. Vet. Bras. 37(12):1401-1404. <http:// dx.doi.org/10.1590/s0100-736x2017001200007>

Smith R.L. \& Bababunmi E.A. 1980. Toxicology in the Tropics. Taylor and Francis Ltd., London. 280p.

Steyn D.G. 1931. Investigations into the cause of alopecia (kaalsiekte) in kids and lambs. 17th Report of the Director of Veterinary Services and Animal Industry, p.729-756.

Taylor J.B. \& Strickland J.R. 2002. Appearence and disappearance of swainsonine in serum and milk of lactanting ruminantes with nursing young following a singledose axposure to swainsonine (locoweed; Oxytropis sericea). J. Anim. Sci. 80(9):2476-2484. <PMid:12350025>

Throckmorton J.C., Cheeke P.R., Patton N.M., Arscott G.H. \& Jolliff G.D. 1981 Evaluation of meadowfoam (Limnanthes alba) meal as a feedstuff for broiler chicks and weanling rabbits. Can. J. Anim. Sci. 61(3):735-742. <http:// dx.doi.org/10.4141/cjas81-088>

Tokarnia C.H., Brito M.F., Barbosa J.D., Peixoto P.V. \& Dobereiner J. 2012 Planta Tóxicas do Brasil para Animais de Produção. $2^{\mathrm{a}}$ ed. Helianthus, Rio de Janeiro, p.29-71.

Vahrmeijer J. 1981. Poisonous Plants of Southern Africa that Cause Stock Loses. Tafelberg, Cape Town. 168p.

Valsechi O.A. 2001. O leite e seus derivados. Postgraduate Program in Production Engineering, Universidade Federal de São Carlos, Araras, SP. 35p.

Vasconcelos J.S., Riet-Correa F., Dantas A.F.M., Medeiros R.M.T., Galiza G.J.N., Oliveira D.M. \& Pessoa A.F.A. 2008. Intoxicação por Mascagnia rigida (Malpighiaceae) em ovinos e caprinos. Pesq. Vet. Bras. 28(10):521-526. <http://dx.doi.org/10.1590/S0100-736X2008001000013>

White R.D. \& Cheeke P.R. 1983. Meadowfoam (Limnunthes alba) meal as a feedstuff for dairy goats and toxicologic activity of the milk. Can. J. Anim. Sci. 63(2):391-398. <http://dx.doi.org/10.4141/cjas83-048>. 